\title{
Anti-Insulin Antibodies in Insulin Immunometric Assays: A Still Possible Pitfall
}

\author{
Rémy Sapin \\ Laboratoire Universitaire de Biophysique, CNRS URA 1173, Faculté de Médecine, Strasbourg, France
}

Summary: Insulin was assayed directly using radioimmunoassay and immunometric assay in 31 sera containing anti-insulin antibodies. Anti-insulin antibodies were determined by radio-binding-assay. Insulin measurements were compared with those of free (unbound to antibodies, polyethylene glycol precipitated) insulin measurements. Compared with free insulin concentrations, radioimmunoassay and immunometric assay yielded falsely increased insulin results. The degree of overestimation by radioimmunoassay and by immunometric assay correlated with the antiinsulin antibody value. Anti-insulin antibodies still remain a possible pitfall in the insulin-specific immunometric assays which are now being widely used.

\section{Introduction}

The availability of monoclonal antibodies to well-defined sequences has made it possible to develop noncompetitive two-site immunometric assays with a high specificity for the intact insulin molecule (1). Compared with previous competitive one-site radioimmunoassays (2) these new assays, now commercially available, have greatly improved the specificity and sensitivity of plasma insulin measurements (3). However, as recently reviewed by Crowthers et al. (4), many problems are still encountered in measuring insulin: sample collection and storage, standards and quality control samples and matrix effects. Insulin radioimmunoassay measurements were also well-known to be falsified by endogenous anti-insulin antibodies $(5,6)$. Anti-insulin antibodies are produced during treatment with porcine or human insulin, and anti-insulin autoantibodies are present in prediabetes before any treatment with insulin (7). The aim of this study was to establish whether anti-insulin antibodies interfere with the now widely used insulin immunometric assays and thus influence the interpretation of insulin concentration.

\section{Material and Methods \\ Methods}

The presence of free anti-insulin antibodies (not complexed with circulating insulin) was determined using the radioimmunoprecipitation technique in liquid phase: radio-binding-assay (Sanofi Pasteur, Marnes la Coquette, France). As recommended by international workshops (8) this assay uses a monocomponent A 14 human insulin tracer. The positivity threshold was fixed by the manufacturer at $5.5 \%$. A binding percentage greater than this positivity threshold indicates the presence of anti-insulin antibodies.

Insulin concentrations were determined with a radioimmunoassay kit from Sanofi Pasteur involving a guinea-pig polyclonal antibody.
The percentage of cross reaction with proinsulin is $40 \%$. Insulin concentrations were further determined with a microparticle enzyme immunometric assay kit (Abbott, Abbott Park, USA) which allows insulin determination in the absence of cross-reactivity with proinsulin and proinsulin-like molecules (9). This method is fully automated on the IMx system (Abbott). Both methods are calibrated against the WHO 66/304 standard.

Free (unbound to anti-insulin antibodies) insulin was determined with the radioimmunoassay kit after precipitation of endogenous immune complexes by polyethylene glycol (10). Free insulin represents the biologically active form of insulin.

Specimens

We selected 31 sera from insulin-treated insulin-dependent diabetic patients. These samples contained anti-insulin antibodies in proportions determined by radio-binding-assay results ranging from 6.1 to $67 \%$.

\section{Results}

Radioimmunoassay insulin values ranged from 18.3 to $295 \mathrm{mU} / \mathrm{l}$, immunometric assay values from 5.7 to 220.5 $\mathrm{mU} / \mathrm{l}$, and free insulin concentrations from 2 to 45.5 $\mathrm{mU} / \mathrm{l}$ (fig. 1). Comparison of the paired radioimmunoassay or immunometric assay results with free insulin concentrations showed a significant fall $(\mathrm{t}=6.25, p=$ $7 \cdot 10^{-7}$ and $\mathrm{t}=5.82, p=2 \cdot 10^{-6}$, respectively). Compared to radioimmunoassay, immunometric results were significantly lower $\left(\mathrm{t}=3.95, p=4 \cdot 10^{-4}\right)$.

A strong correlation was observed between the overestimation of insulin concentration, measured by either radioimmunoassay or immunometric assay, determined as $100 \times$ ([insulin] - [free insulin])/[free insulin] and the percentage of anti-insulin antibodies measured by radio-binding-assay (fig. 2). The correlation was similar for radioimmunoassay $(r=0.79)$ and immunometric assay $(r=0.77)$. The degree of interference, as appreciated by the slope of the regression line, was greater with 


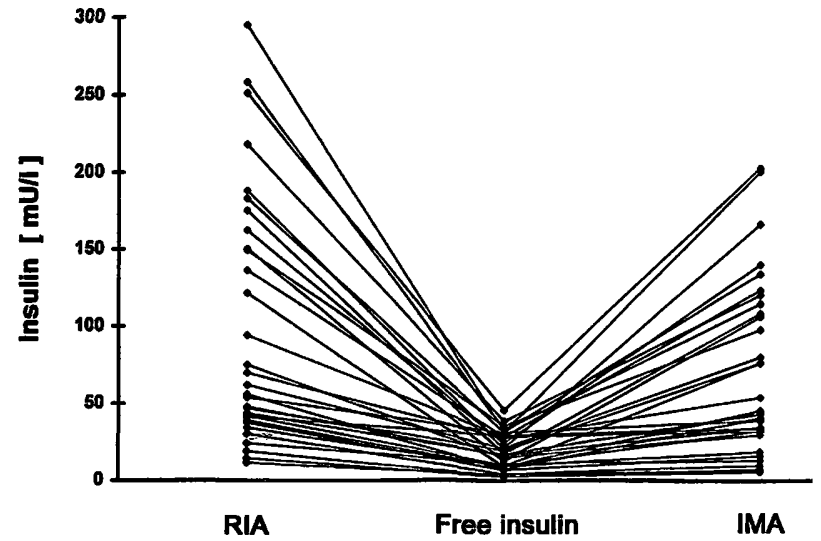

Fig. 1 Comparison of insulin measured by radioimmunoassay (RIA) and by immunometric assay (IMA) with free (polythylene glycol precipitated) insulin concentration in 31 anti-insulin antibody positive sera.

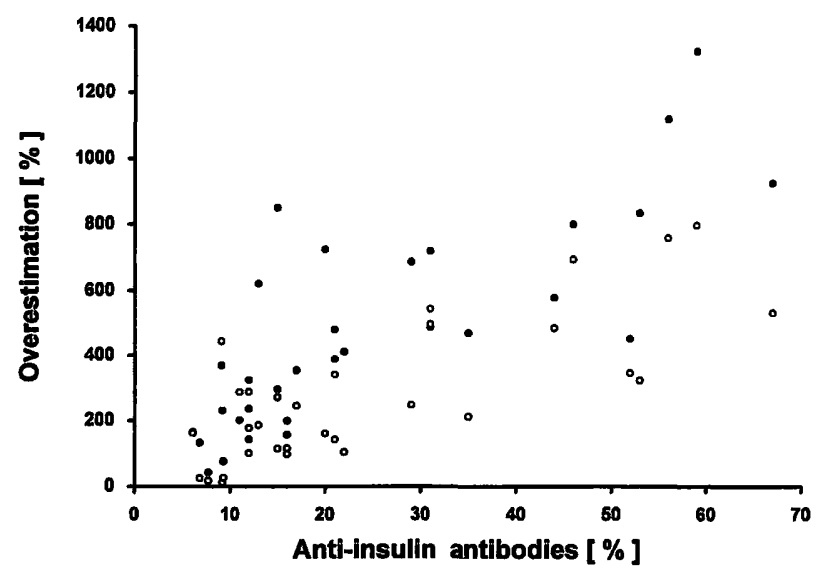

Fig. 2 Association of insulin overestimation determined as $100 \times$ ([insulin] - [free insulin])/[free insulin] with anti-insulin antibody percent determined by radio-binding-assay. Insulin measured by radioimmunoassay (dark circles) and immunometric assay (open circles).

radioimmunoassay $(\mathrm{y}=14.2 \mathrm{x}+120)$ than with immunometric assay $(y=9.4 x+47)$.

\section{Discussion}

It was demonstrated, long ago, that anti-insulin antibodies interfere with the radioimmunoassay of insulin. The effect of endogenous anti-insulin antibodies is to increase the total amount of labelled insulin bound to endogenous human and exogenous guinea-pig antibodies and to reduce the amount of labelled insulin bound to exogenous guinea-pig antibodies. The results of competitive one-site radioimmunoassay depend on the separation method used. Non-specific precipitation of immunoglobulin complexes, with, for example, polyethylene glycol, leads to false underestimated values due to overprecipitation of the bound tracer. The double-antibody, involved in the Sanofi radioimmunoassay used in this study, or coated tube technology, used in today's radioimmunoassays, results in overestimation, as too little of the tracer is specifically bound.
Our results show clearly that anti-insulin antibodies can also interfere with insulin immunometric determinations. Immunometric assay recognised, at least partially, insulin bound to endogenous antibodies, yielding increased insulin values as compared with free insulin concentrations. The degree of overestimation in an immunometric assay depends, at least theoretically and especially for small analyte molecules with a limited number of antibody binding sites, such as insulin, on the comparative avidity of autoantibodies and of the catcher and tracer antibodies used in the assay. If the avidity of the assay antibodies exceeds that of autoantibodies, the measured concentration will tend towards the total (free and antibody-bound) insulin concentration, i. e. yield an overestimation of the biologically active (free) insulin in the sample. But, if the assay antibodies are less avid than autoantibodies, the measured concentration will tend towards the free insulin concentration, as little or no displacement of the autoantibody-insulin complex takes place during the incubation time.

This may explain why the Abbott immunometric assay was more sensitive to interference from anti-insulin antibodies than the enzyme immunoassay (ELISA) studied by Andersen et al. (11) who observed insulin concentrations close to free insulin in sera containing insulin antibodies with a bound fraction below $25 \%$. Under the same conditions, with the Abbott kit, the mean overestimation was $165 \%$.

In sera containing anti-insulin antibodies, when compared with free insulin concentrations, insulin results by immunometric assay are overestimated, but, when compared with total insulin levels, they may be underestimated (12). It is generally stated that anti-analyte antibodies may yield a positive interference (overestimation) when the result is compared with the free analyte concentration (insulin assay for example) or a negative interference (underestimation) when the result is compared with the total analyte concentration (thyroglobulin assay for example) (13). The relevant analyte concentration is, in the first case, that which corresponds to its biologically active form (free form), and in the second case, that which shows a residual secretion by thyroid after thyroidectomy (total form).

\section{Conclusion}

Interference from anti-insulin antibodies, yielding increased values, still remains a topical pitfall in insulin immunometric assays. Care must be taken in the interpretation of immunometric insulin results when anti-insulin antibodies are present.

The solid phase antigen immunoassay described by Wood et al. (14) could be an interesting approach to settle the issue of an antibody interference-free assay, be- 
cause free thyroxin assays based on this methodology have been shown to be much less sensitive to anti-thyroxin autoantibody interference than previous labelled antigen immunoassays (15).

\section{References}

1. Sobey WJ, Beer SF, Carrington CA, Clark PMS, Frank BH, Gray IP, et al. Sensitive and specific two-site immunoradiometric assays for human insulin, proinsulin, 65-66 split and 3233 split proinsulins. Biochem J 1989; 260:535-41.

2. Yalow RS, Berson SA. Assay of plasma insulin in human subjects by immunological methods. Nature $1959 ; 184: 1648-9$.

3. Sapin R. Recent insulin immunoassays: improvements and limits. J Clin Ligand Assay 1996; 19 (1 Suppl):100S-110S.

4. Crowthers NJ, Gray IP. Immunometric assays of insulin and its precursors. J Clin Ligand Assay 1996; 19:112-20.

5. Armitage M, Wilkin T, Wood P, Casey C, Loveless R. Insulin autoantibodies and insulin assay. Diabetes $1988 ; 37: 1392-6$.

6. Clark PMS, Hales CN. How to measure plasma insulin. Diabetes/Metabolism Reviews 1994; 10:79-90.

7. Sodoyez JC, Koch M, Sodoyez-Goffaux F. Anticorps anti-insuline: méthodologie et implications cliniques. Diabetes Metab $1991 ; 17: 255-69$.

8. Kuglin B, Kolb H, Greenbaum C, Maclaren NK, Lernmark A, Palmer JP. The fourth international workshop on the standardisation of insulin autoantibody measurement. Diabetologia 1990; 33:638-9.

9. Monti LD, Sandoli EP, Phan VC, Piatti PM, Costa S, Secchi A, et al. A sensitive and reliable method for assaying true human insulin without interaction with human proinsulin-like molecules. Acta Diabetol 1995; 32:57-63.

10. Amqvist $H$, Olsson PO, von Schenck $H$. Free and total insulin as determined after precipitation with polyethylene glycol: an-

\section{Acknowledgements}

The author is very grateful to Mrs. Nathalie Heider for reviewing the English of this manuscript.

alytical characteristics and effects of sample handling and storage. Clin Chem 1987; 33:93-6.

11. Andersen L, Dinesen B, Jorgensen PN, Poulsen F, Roder M. Enzyme immunoassay for intact human insulin in serum or plasma. Clin Chem 1993; 39:578-82.

12. Gennaro WD, Van Norman JD. Quantitation of free, total, and antibody-bound insulin in insulin-treated diabetics. Clin Chem $1975 ; 21: 873-9$.

13. Spencer CA, Takeuchi M, Kazarosyan M. Current status and performance goals for serum thyroglobulin assays. Clin Chem 1996; 42:164-73.

14. Wood WG, Fricke H, von Klitzing L, Strasburger CJ, Scriba PC. Solid phase antigen luminescent immunoassays (SPALT) for the determination of insulin, insulin antibodies and gentamicin levels in human serum. J Clin Chem Clin Biochem 1982; 20:825-31.

15. Sheehan CP, Cristofides ND. One-step, labeled antibody assay for measuring free thyroxin. II. Performance in a multicenter trial. Clin Chem 1992; 38:19-25.

Received January 3/February 17, 1997

Corresponding author: Dr. Rémy Sapin, Institut de Physique. Biologique, Faculté de Médecine, 4 rue Kirschleger, F-67085 Strasbourg Cedex, France 
